Journal of Contemporary Research in Social Sciences

ISSN : 2641-0249

Vol. 3, No. 1, pp. 11-27.

2021

Publisher: Learning Gate

DOI: 10.33094/26410249.2021.31.11.27

(C) 2021 by the authors; licensee Learning Gate

\title{
An Exploratory Factor Analysis of Work-Attributes of Pharmaceutical Sales Workforce during COVID-19 Lockdown
}

\author{
Theophilus Ehidiamen OAMEN \\ Department of Clinical Pharmacy and Pharmacy Administration Faculty of Pharmacy, Obafemi Awolowo University Ife, Osun State, \\ Nigeria. \\ Email: oamentheo.publication@gmail.com
}

Received: 26 January 202 1; Revised: 12 February 2021; Accepted: 23 February 202 1; Published: 5 March 2021

Abstract: The global COVID-19 pandemic has re-defined work operations and work-attributes in our business environment. The conventional day-to-day activities and work-attributes of the supply chain sales workforce have changed due to the compulsory lockdown and restrictions enforced by national governments worldwide. Hence, there is the need to identify the key constructs embedded in the current realities. This research gap has not been investigated using exploratory factor analysis (EFA). The objective of this study was to evaluate pharmaceutical sales representatives' (PSRs) perception of selected work-attributes by using EFA to develop a framework of constructs. A cross-sectional, quantitative research technique was used. A 13-item structured questionnaire was administered using the purposive sampling method to 17O PSRs in Nigeria. The questionnaire was based on a 5point Likert scale ranging from 'strongly disagree (1) to strongly agree' (5). Descriptive and Inferential statistics using SPSS 23. Work-attributes were extracted using two-factor extraction methods; Principal component analysis (PCA) with orthogonal rotation and Principal axis factoring $(P A F)$ with oblique rotation. Parallel analysis (PA) using simulated data analysis of 170 sample size and 13-item variables was executed using SPSS syntax. EFA model fit characteristics were satisfactory within criteria level. PAF gave more parsimonious constructs with 3 components extracted. The constructs were reduced to 1 after applying $P A$. The focal workattributes were: Increased workload, Information/enlightenment provider, increased sales of products, and received recognition/appreciation for sales efforts during the lockdown. The study developed a validated summary of key work-attributes. Provided information for conducting EFA in pharmaceutical sales and marketing operations.

Keywords: Factor analysis, Exploratory factor analysis, Orthogonal rotation, Oblique rotation, Pharmaceutical sales representatives, Work-attributes, COVID-19, Principal component analysis, Parallel analysis, Supply chain.

\section{Introduction}

Factor analysis is a structural equation (quantitative) technique used to simplify, further explain large, complex data, and generate linked relationships that may occur among a set of seemingly unrelated observed variables (Reio Jr \& Shuck, 2015; Thompson, 2004). Factor Analysis has been extensively applied in many disciplines especially in the social, behavioral, and management sciences (Nimalathasan, 2009) relationship marketing research for large data reduction without loss of essential information (Luigi, Țichindelean, \& Vinerean, 2013) education research studies (Ozturk, 2011) practice research (Schreiber, 2020; Van De Tran, 2019; Watterson, Look, Steege, \& Chui, 2020): research guidelines for factor analytic studies (Berliner, 2002; Goretzko, Pham, \& Bühner, 2019; Matsunaga, 2010; Nimalathasan, 2009; Schreiber, 2020).

Several reporting algorithms have been proposed in the literature for properly conducting factor analysis (FA) in social, management, and behavioral sciences (Goretzko et al., 2019; Matsunaga, 2010; Ozturk, 2011; Schreiber, 2020). However, in social and administrative pharmacy research, particularly in 
pharmaceutical sales and marketing practice, there are many untapped applications of this quantitative tool (Schreiber, 2020; Van De Tran, 2019; Watterson et al., 2020).

Furthermore, there is an increasing demand for research in the pharmaceutical sales and marketing industry relating to the effects of the COVID-19 pandemic, where the paradigm of job description and processes is rapidly changing as firms and employees continue to adapt to these effects daily. It is useful to have a better understanding of how this paradigm shift affects the work-attributes of healthcare supply chain staff, in particular, pharmaceutical sales representatives (PSRs). This perhaps will support characterization into constructs to aid proper understanding and prioritization of roles and functions, as required. Hence, the use of quantitative techniques such as Factor analysis (FA) to derive constructs, facilitate parsimony, understanding, and as well as acquire the desired skill set for practitioners.

Therefore, the main purpose of this empirical study is the application of exploratory factor analysis (EFA) to the responses' obtained from a 13-item structured questionnaire administered to a pool of pharmaceutical sales representatives (PSRs) in Nigeria. Study questions were used to assess PSRs' perception of the relevance of work-attributes or characteristics during the period of COVID-19 lockdown in Nigeria. This study employed the use of two methods of factor extraction: Principal component analysis (PCA) versus Principal axis factoring (PAF) methods respectively. The rationale was aimed at evaluating from two analytical perspectives, the output of factor extraction with the primary objective of generating parsimonious elements of the constructs.

\subsection{Conceptual Framework of the Study}

Pharmaceutical sales representatives are involved in the supply chain of pharmaceutical products, services, and medical information dissemination. Their core responsibilities include drug/product information services, drug supply, interaction with healthcare professionals (HCPs), and a critical interface between drug retailers and the final consumer or patient (Oamen, 202 1; Obuaku, 2014; Ugbam \& Okoro, 2017; WHO, 2010). However, the occurrence of COVID-19 has by effects, expanded the role and operations of PSRs to include other related work-attributes about: issues with access to health care professionals (HCPs), involvement in COVID screening, business operations remodeling, and community engagement (Ayati, Saiyarsarai, \& Nikfar, 2020; Elbeddini \& Yeats, 2020; Gray, Hoffman, \& Mansfield, 2020; Oamen, 2021).

Therefore, this study empirically assessed the perception of respondents about the relevance of their multi-faceted work-attributes in the face of COVID-19 lockdown and restrictions as experienced in many countries, globally. A study of pharmaceutical sales representatives' perception of the relevance of the overall work attributes in Nigeria using exploratory factor analysis (EFA) is thus required. In this study, two extraction perspectives were deployed; Principal Component Analysis (PCA) and Principal Axis Factoring (PAF). Several studies have raised methodological arguments about the relevance and applicability of factor extraction methods; PCA and PAF. While some advocate the use of PCA to develop parsimony and constructs (Henson, Capraro, \& Capraro, 2004; Pett, Lackey, \& Sullivan, 2003; Tabachnick \& Fidell, 2007). Other studies suggest the use of PAF based on the premise that there could be some correlation or causal relationships among items/variables in a given study and hence generalizable to the general population (Conway \& Huffcutt, 2003; Izquierdo, Olea, \& Abad, 2014; Kahn, 2006; Mvududu \& Sink, 2013). This study applied both methodological perspectives in its factor analysis modeling to draw relationships and possible correlations between the observed variables and latent (unobserved variables). Therefore, this exploratory analysis provided the theoretical context for further model fit validation of research instruments using Confirmatory Factor analysis (CFA). It is the focus of this study that more research evaluations in pharmaceutical sales and marketing Industry should adopt this quantitative research technique.

\subsection{Objectives of the Study}

The main objectives of this study are enumerated as follows; 
1. Evaluate the perception of the relevance of work-attributes of PSRs using exploratory factor analysis.

2. Use outcome/s of study to produce a working Factor analysis framework for application in pharmaceutical sales and marketing research.

\subsection{The hypothesis of the Study}

The hypothesis of the study was stated in the null as follows:

1. HO1: There is no confirmed measure of construct validity or reliability from the dataset for exploratory factor analysis to be performed adequately.

2. HO2: There is no difference in the output of factor extraction methods; Principal component analysis (with varimax rotation) versus Principal axis factoring (with Promax) method.

3. HO3; There is no significant difference between the actual eigenvalues from the dataset and simulated eigenvalues output of Parallel Analysis (PA).

4. HO4: There is no meaningful ranked difference between observed variables (work-attributes) in each determined constructs.

\section{Research Methodology}

\subsection{Questionnaire Design}

The questionnaire survey method was adopted for this research as a tool to collect required empirical data. A total of 13-survey items were generated from the literature review process and interaction with Industry experts. The questionnaire consists of 2 main parts; Part one is comprised of relevant demographic data showing age, years of practice, and type of firm. Part two comprised of 13item questions based on a 5-point Likert scale ranging from 'strongly disagree (1), disagree (2), neither agree nor disagree (3). Agree (4), and strongly agree' (5).

\subsection{Study Population}

The study population comprised of Pharmaceutical Sales Representatives from the six geopolitical zones (south-west-SW, south-south-SS, south-east-SE, north-central-NC, north-east-NE \& north-west$\mathrm{NW}$ ) in Nigeria.

\subsection{Sample Size Determination}

Sample size determination was based on respondents to item ratio of 10:1 as recommended for participants greater than 100. This will enable replicability of research (Izquierdo et al., 2014; Reio Jr \& Shuck, 2015; Tabachnick \& Fidell, 2007). In this study, 170 respondents answered a 13-item questionnaire with a greater than $13: 1$ ratio.

\subsection{Sampling Design}

The sample consists of 170 respondents (valid responses) out of 300 structured questionnaires administered to pharmaceutical sales representatives across the six geopolitical zones in Nigeria. . However, due to the absence of a reliable database, a purposive sampling method was used. The response rate was $75.6 \%$.

\subsection{Data Collection}

The structured questionnaire contained 13-item Likert scale questions examining the perception of respondents about the relevance of work and work-related attributes during the period of lockdown in Nigeria which spanned from March 2020 to August 2020. 300 questionnaires in total were administered across the six geopolitical zones. Consent was obtained from respondents' through the provision of unique personal identifiers. 


\subsection{EPA Measures}

The correlation Matrix considered values less than -0.8 or greater than 0.8 . Value/s greater than 0.8 or below -0.8 imply that the value is an identity matrix, hence unacceptable. (See Appendix A). Communalities table accepts values equal and/or above 0.5 and rejects values below 0.5. Determinant values of the correlation matrix must be greater than 0.0001 , to be considered significant/acceptable. An anti-image matrix was also determined (see Appendix B). Eigenvalues below 1 are considered unacceptable/redundant. Therefore, Eigenvalues greater than 1 are the preferred extraction criteria as shown in Figure 1. Eigenvalue measures the degree of variability of explanatory variables/factors accounted by a given factor. The total variance of factors must be equal to or greater than $50 \%$. (Cokluk \& Koçak, 2016; Cronbach, 1946; Debasish, 2004; Izquierdo et al., 2014).

\subsection{Data Analysis Tools}

Descriptive statistics such as Mean and Standard deviation SPSS version 23 was used to compute Factor analysis (FA) for the dataset. Two methods of factor extraction were deployed in this study; Principal component analysis (PCA) with varimax rotation and Principal Axis Factoring (PAF) with Promax rotation (Fabrigar, Wegener, MacCallum, \& Straham, 1999; Henson et al., 2004; Kahn, 2006; Reio Jr \& Shuck, 2015; Schreiber, 2020).

\subsection{Factor Extraction Method and Factor Loadings Criteria}

In this study, PCA and PAF were applied comparatively. PCA method presented simple representations of the structure of the latent variables (Mvududu \& Sink, 2013; Nimon, Zigarmi, Houson, Witt, \& Diehl, 2011). PAF was used to provide a more robust understanding of the latent structure of the observed variables under consideration (Henson et al., 2004; Treiblmaier \& Filzmoser, 2010). Furthermore, this study interpreted variables as significant if they present factor loadings equal to or more than 0.5. (Debasish, 2004).

\subsection{Test of Reliability and Validity}

Cronbach alpha value of surveyed data was set at 0.7 baselines for internal reliability. Kaiser-MeyerOlkin (KMO) measure of sampling Adequacy was set at 0.5 baselines. KMO measure was set from the following criteria; a measure of $>0.9=$ marvelous, $>0.8=$ meritorious, $>0.7=$ middling, $>0.6=$ mediocre, $>0.5=$ miserable and $<0.5=$ unacceptable. 0.5 is considered the absolute minimum validity value. KMO ensures that the distribution of observed values is satisfactorily adequate to conduct FA (Cronbach, 1946; Matsunaga, 2010; Tabachnick \& Fidell, 2007).

\subsubsection{Horn's Parallel Analysis (PA)}

Horn's Parallel Analysis of the dataset (sample size $=170$, Number of items $=13,95^{\text {th }}$ percentile with 1000 iterations) using SPSS syntax was used to determine factors to be retained (Horn, 1965; Ledesma \& Valero-Mora, 2007; O'Connor, 2000). Parallel Analysis (PA) was applied by comparing Eigenvalues computed from actual data set with simulated dataset obtained from Parallel analysis (PA). When simulated Eigenvalues are greater than actual data Eigenvalues, the factor is removed and vice versa. (Cokluk \& Koçak, 2016). (See PA output in Appendix C).

\section{Results and Discussion}

In this study, over $60 \%$ of respondents fell within the age bracket of 26 to 35 years as well as over $65 \%$ with below a year to 10 years of working experience in the pharmaceutical sales and marketing Industry. The minimum education level of respondents was first-degree polytechnic or University.

Table 1 shows the mean distribution of responses of respondents to the various items of the questionnaire; with the work-attributes (Q1-Enlightenment \& Information provider) \& (Q13Involvement in COVID screening) with the highest and lowest mean response scores respectively. Invariably, this implies that information \& enlightenment about COVID disease and prevention had 
dominated the daily activities of PSRs. This is a sharp contrast from the norm in pharmaceutical sales and marketing operations, where firm-specific information dissemination activities geared to their product sales objectives are the practice (Elbeddini \& Yeats, 2020; Gray et al., 2020). Conversely, the lowest score for item Q13 suggests that PSRs had little or no participation in actual COVID screening activities. This is an area to be explored by governments in developing countries where there is a paucity of trained and skilled first-line healthcare workers (Adeloye et al., 2017; Afriyie, Nyoni, \& Ahmat, 2019). PSRs' can provide augmented services in this regard.

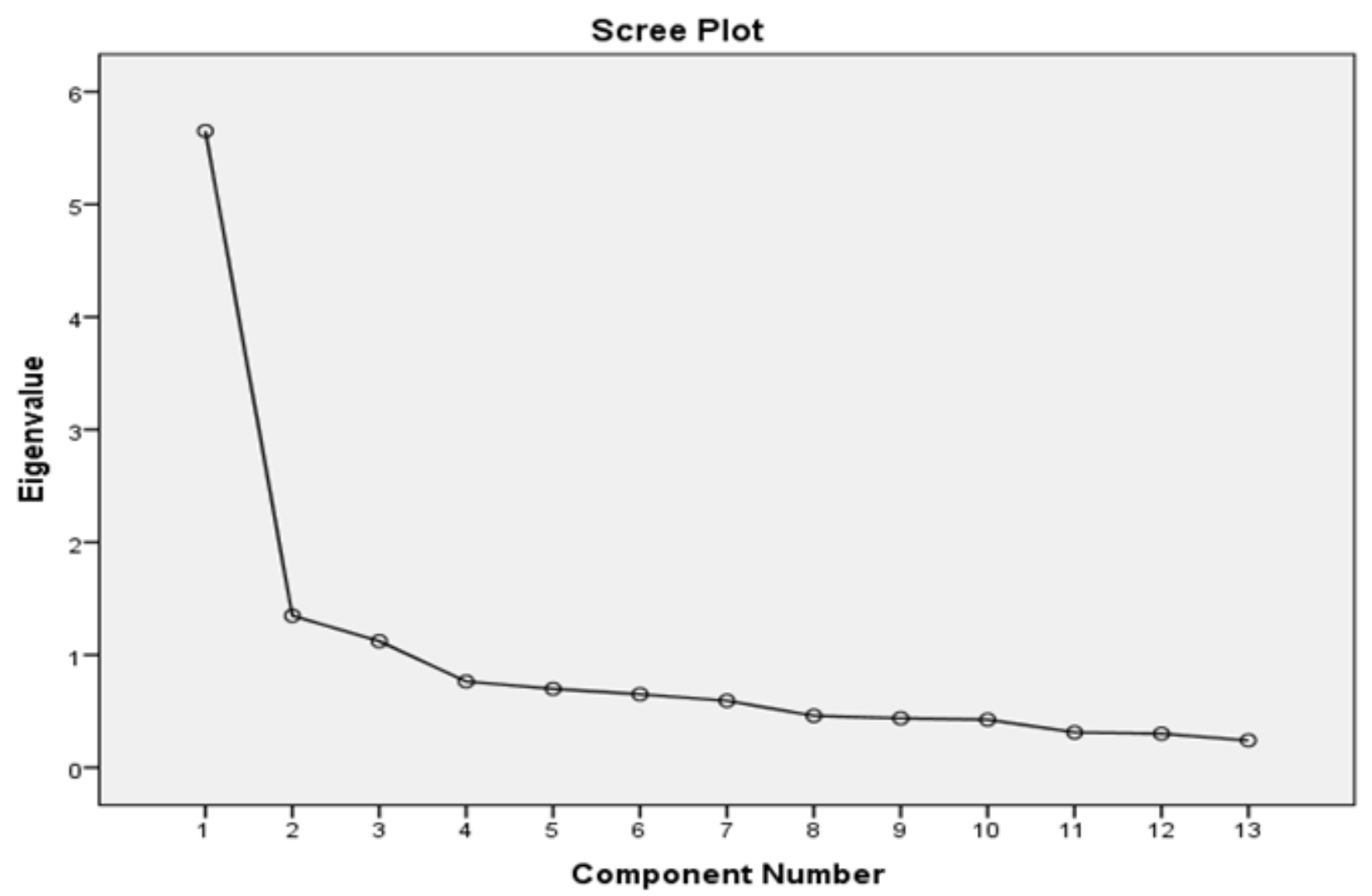

Figure-1.

Scree plot of Eigen values from dataset.

Table 2 shows that the measures of construct validity and adequacy were met by the dataset. In the same vein, the correlation matrix was found to satisfy the condition and hence confirms that correlation estimates of items were not due to chance. This provides a basis for the application of the factor analysis procedure as all pre-conditions have been fully satisfied. (See correlation matrix \& anti-image matrix in Appendix A \& B respectively). Therefore, there is confirmed the construct validity of the dataset of the study and the results of exploratory factor analysis are valid, and therefore, the null hypothesis (HO1) was rejected.

In this study, as shown in Table 3, three (3) latent variables (Constructs) were derived from the factor extraction process; 1) Group 1: Sales-related activities, 2) Group 2: Communication/Accessrelated activities, and 3) Group 3: COVID-related activities. To achieve this, two-factor extraction methods were adopted; default Principal component analysis with orthogonal rotation (varimax) with the assumption that the factors are unrelated and Principal axis factoring with oblique rotation (Promax). Both methods produced similar output along the three constructs derived from the analysis. 
Table-1.

Descriptive Statistics of Key Work Attributes of Pharmaceutical sales representatives during COVID-19 lockdown.

\begin{tabular}{l|l|c|c|c}
\hline Items & $\begin{array}{l}\text { Work Attributes of Pharma. Sales } \\
\text { Representatives }\end{array}$ & Mean & Std. Deviation & Analysis N \\
\hline Q1 & Enlightenment \& Information Provider & 3.64 & 1.335 & 170 \\
\hline Q2 & $\begin{array}{l}\text { Received recognition/commendation for your sales } \\
\text { efforts during the pandemic }\end{array}$ & 3.07 & 1.357 & 170 \\
\hline Q3 & Increased workload & 3.13 & 1.498 & 170 \\
\hline Q4 & Increased sales of your products & 2.18 & 1.45 & 170 \\
\hline Q6 & Involved in community education & 2.99 & 1.416 & 170 \\
\hline Q7 & Limproved access to your customers access to your customers & 2.95 & 1.516 & 170 \\
\hline Q8 & $\begin{array}{l}\text { Observed compliance by people during lockdown } \\
\text { period }\end{array}$ & 3.31 & 1.443 & 170 \\
\hline Q9 & Enjoyed community appreciation of your efforts & 2.86 & 1.443 & 170 \\
\hline Q10 & Virtual consultation with clients/customers & 3.26 & 1.404 & 170 \\
\hline Q11 & $\begin{array}{l}\text { Limited access to Doctors, nurses pharmacists } \\
\text { (HCPs) }\end{array}$ & 2.98 & 1.467 & 170 \\
\hline Q12 & Made fresh contacts/new opportunities for business & 3.09 & 1.47 & 170 \\
\hline
\end{tabular}

Table-2.

Exploratory Factor Analysis (EFA) Measures and Results.

\begin{tabular}{|c|c|c|c|c|}
\hline $\begin{array}{l}\text { Measures of } \\
\text { Adequacy }\end{array}$ & Attribute & $\begin{array}{l}\text { Threshold } \\
\text { (cut-off values) }\end{array}$ & Study results & Inference \\
\hline $\begin{array}{l}\text { Kaiser=Meyer-Olkin } \\
(\text { KMO })\end{array}$ & $\begin{array}{l}\text { A measure of sample } \\
\text { adequacy of distribution }\end{array}$ & $\begin{array}{l}\text { Marvelous }>0.9 \\
\text { Unacceptable }<0.5\end{array}$ & 0.872 & satisfactory \\
\hline $\begin{array}{l}\text { Bartlett's Test of } \\
\text { Sphericity }\end{array}$ & $\begin{array}{l}\text { A measure of multivariate } \\
\text { normality }\end{array}$ & $<0.05$ & 0.0001 & satisfactory \\
\hline $\begin{array}{l}\text { Cronbach Alpha test } \\
\text { of Internal reliability }\end{array}$ & $\begin{array}{l}\text { A measure of internal } \\
\text { reliability }\end{array}$ & criterion $\geq 0.7$ & 0.888 & satisfactory \\
\hline Goodness of fit & $\begin{array}{l}\text { Shows degree sample fits } \\
\text { the population }\end{array}$ & value $<0.05$ & 0.0001 & satisfactory \\
\hline $\begin{array}{l}\text { Anti-Image } \\
\text { Correlation }\end{array}$ & $\begin{array}{l}\text { A measure of the } \\
\text { correlation of items }\end{array}$ & between -0.8 and 0.8 & $\begin{array}{l}>0.5 \text { but less } \\
\text { than } 0.8\end{array}$ & satisfactory \\
\hline Communalities & Extraction of factors & $>0.5$ & $\begin{array}{l}\text { acceptable } \\
\text { values } \geq 0.5\end{array}$ & satisfactory \\
\hline $\begin{array}{l}\text { Non-redundant } \\
\text { residuals }\end{array}$ & $\begin{array}{l}\text { A measure of an identity } \\
\text { matrix }\end{array}$ & $0.05(5 \%)$ & 0.0003 & satisfactory \\
\hline $\begin{array}{l}\text { Total Variance } \\
\text { explained }\end{array}$ & $\begin{array}{l}\text { A measure of variance by } \\
\text { factors }\end{array}$ & $>50 \%$ & 62.5 & satisfactory \\
\hline
\end{tabular}

Note: Dataset satisfies all the criteria for construct validity. Hence, suitable for EFA. 
Table-3.

Comparative Output Analysis of PAF and PCA Factor extraction Methods.

\begin{tabular}{|c|c|c|c|c|c|}
\hline $\begin{array}{l}\text { Factor } \\
\text { extraction } \\
\text { Method } \\
\end{array}$ & Items & $\begin{array}{l}\text { Principal Component } \\
\text { Analysis (PCA) }\end{array}$ & $\begin{array}{l}\text { Factor } \\
\text { loadings }\end{array}$ & $\begin{array}{l}\text { Principal Axis } \\
\text { Factoring (PAF) }\end{array}$ & $\begin{array}{l}\text { Factor } \\
\text { loadings }\end{array}$ \\
\hline \multirow[t]{5}{*}{ Group 1} & Q3 & Increased workload & 0.83 & Increased Workload & 0.932 \\
\hline & $\mathrm{Q}^{2}$ & $\begin{array}{l}\begin{array}{l}\text { recognition for sales } \\
\text { efforts }\end{array} \\
\end{array}$ & 0.767 & $\begin{array}{l}\text { Recognition for sales } \\
\text { efforts }\end{array}$ & 0.771 \\
\hline & Q1 & $\begin{array}{l}\text { enlightenment } \\
\text { Information }\end{array}$ & 0.686 & $\begin{array}{l}\text { enlightenment } \\
\text { \&Information }\end{array}$ & 0.632 \\
\hline & $\widehat{\mathrm{Q}_{4}}$ & Increased sales & 0.537 & Increased sales & 0.615 \\
\hline & Q12 & $\begin{array}{l}\text { new contacts and } \\
\text { opportunities }\end{array}$ & 0.668 & & \\
\hline Construct 1 & & Sales-related activities & & Sales-related activities & \\
\hline \multirow[t]{5}{*}{ Group 2} & Q11 & limited access to HCPs & 0.792 & limited access to HCPs & 0.843 \\
\hline & $\widetilde{Q} 7$ & Virtual consultation & 0.611 & Virtual consultation & 0.59 \\
\hline & Q8 & Observed compliance & 0.643 & Observed compliance & 0.621 \\
\hline & Q10 & $\begin{array}{l}\text { limited access to } \\
\text { customers }\end{array}$ & 0.757 & $\begin{array}{l}\text { limited access to } \\
\text { customers }\end{array}$ & 0.685 \\
\hline & Q9 & community appreciation & 0.508 & & \\
\hline Construct II & & $\begin{array}{l}\text { Communication/Access- } \\
\text { related activities }\end{array}$ & & $\begin{array}{l}\text { Communication/Access- } \\
\text { related activities }\end{array}$ & \\
\hline \multirow[t]{3}{*}{ Group 3} & Q13 & COVID screening & 0.859 & COVID Screening & 0.923 \\
\hline & Q5 & Community education & 0.707 & Community education & 0.561 \\
\hline & Q6 & $\begin{array}{l}\text { Improved access to } \\
\text { customers }\end{array}$ & 0.543 & & \\
\hline Construct III & & $\begin{array}{l}\text { COVID-related } \\
\text { activities }\end{array}$ & & $\begin{array}{l}\text { COVID-related } \\
\text { activities }\end{array}$ & \\
\hline $\begin{array}{l}\text { No. of factors } \\
\text { extracted }\end{array}$ & & 13 & & 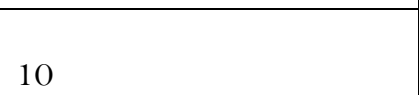 & \\
\hline $\begin{array}{l}\text { Type of } \\
\text { rotation }\end{array}$ & & Varimax (orthogonal) & & Promax (Oblique) & \\
\hline $\begin{array}{l}\text { Preferred } \\
\text { Method }\end{array}$ & & \multicolumn{4}{|c|}{$\begin{array}{l}\text { The principal axis factoring method (PAF) is preferred as it extracted items } \\
\text { that best describe the constructs }\end{array}$} \\
\hline
\end{tabular}

Group 1 with Sales-related activities had Q1, Q2, Q3, \& Q4 in PCA \& PAF. However, PAF excluded Q12 (made fresh contacts \& opportunities for business). Similarly, the PAF technique also eliminated Q4 (community appreciation for efforts during COVID) and Q6 (improved access to customers) from Group 2 and 3 respectively. This was also premised on the fact that both attributes have been captured by other items in both groups. This exclusion by PAF is justified because the items/factors Q3- Increased workload \& Q4-Increased product sales already presuppose by qualification that new opportunities/contacts for business were explored. At face value, PAF gave more precise parsimony of work-attributes in this group. Hence, there is a consequential difference in the output of factor extraction methods; Principal component analysis (with varimax rotation) versus Principal axis factoring (with promax) method. Hence, the null hypothesis (HO2) was rejected. Furthermore, the implications of the output from PAF and PCA is supported by research studies that placed preference 
for PAF especially in datasets that may have inherent causal links or underlying theme or theory (Matsunaga, 2010; Mvududu \& Sink, 2013). This strengthen the assertion by studies which showed that it gives more robust and accurate estimations of constructs (Dahling, Chau, Mayer, \& Gregory, 2012; Kahn, 2006; Nimon et al., 2011; Tabachnick \& Fidell, 2007). Therefore, as shown in Table 4, this study preferred PAF method with promax rotation on four premises; a) constructs are well represented or captured by items/factors, b) PAF had relatively higher factor loadings compared to PCA method, c) has minimal repetition of similar or related items, d) 10 items summarized/represented compared to 13 items by PCA.

Table 4.

Pattern Matrix Output of PAF compared to Simulated Eigen Values from Parallel Analysis.

\begin{tabular}{|c|c|c|c|c|c|}
\hline \multirow[b]{2}{*}{ Items } & \multirow{2}{*}{$\begin{array}{l}\text { Key Work Attributes of } \\
\text { Pharmaceutical sales representatives } \\
\text { during COVID-19 lockdown }\end{array}$} & \multicolumn{3}{|c|}{ Component } & \multirow[b]{2}{*}{ Communalities } \\
\hline & & $\begin{array}{c}\text { GROUP } \\
1\end{array}$ & $\begin{array}{l}\text { GROUP } \\
\quad 2\end{array}$ & $\begin{array}{c}\text { GROUP } \\
3\end{array}$ & \\
\hline Q3 & Increased work load & 0.932 & & & 0.699 \\
\hline $\mathrm{Q}^{2}$ & $\begin{array}{l}\text { Received recognition/commendation for } \\
\text { your sales efforts during the pandemic }\end{array}$ & 0.771 & & & 0.641 \\
\hline Q1 & Enlightenment \& Information Provider & 0.632 & & & 0.595 \\
\hline$Q^{4}$ & Increased sales of your products & 0.615 & & & 0.582 \\
\hline Q12 & $\begin{array}{l}\text { Made fresh contacts/new opportunities } \\
\text { for business }\end{array}$ & & & & 0.524 \\
\hline Q11 & $\begin{array}{l}\text { Limited access to Doctors, nurses \& } \\
\text { pharmacists (HCPs) }\end{array}$ & & 0.843 & & 0.676 \\
\hline$Q^{7}$ & Limited access to your customers & & 0.685 & & 0.604 \\
\hline Q8 & $\begin{array}{l}\text { Observed compliance by people during } \\
\text { lock down period }\end{array}$ & & 0.621 & & 0.593 \\
\hline Q10 & $\begin{array}{l}\text { Virtual consultation } \\
\text { clients/customers }\end{array}$ & & 0.590 & & 0.671 \\
\hline Q9 & $\begin{array}{l}\text { Enjoyed community appreciation of your } \\
\text { efforts }\end{array}$ & & & & 0.597 \\
\hline Q13 & 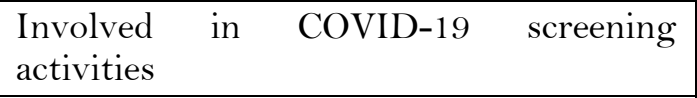 & & & 0.923 & 0.747 \\
\hline Q5 & Involved in community education & & & 0.563 & 0.632 \\
\hline Q6 & Improved access to your customers & & & & 0.559 \\
\hline \multicolumn{2}{|c|}{ EIGEN VALUE } & 5.651 & 1.348 & 1.122 & \\
\hline \multicolumn{2}{|c|}{ Simulated Eigen value (Parallel Analysis) } & 1.489 & 1.362 & 1.267 & \\
\hline \multicolumn{2}{|c|}{$\begin{array}{l}\text { PROPORTION OF VARIANCE accounted for by } \\
\text { items or factors under component GROUPS }\end{array}$} & 43.473 & 10.367 & 8.628 & \\
\hline \multicolumn{2}{|c|}{ CUMULATIVE VARIANCE } & 43.473 & 53.840 & 62.468 & \\
\hline
\end{tabular}

Note: *Eigen applicable at values $\geq 1$, factor loading cutoff- $\geq 0.5$, Extraction Method: Principal Axis Factoring, Rotation Method: Varimax with Kaiser normalization.

Table 5 presents an improvement on the initial solution presented in factor extraction and initial scree plot through the application of Parallel Analysis (PA) method (see Appendix C). Parallel analysis provided a rigorous and robust means to extract factors without the risk of overestimation of latent variables (Cokluk \& Koçak, 2016; Ledesma \& Valero-Mora, 2007; Matsunaga, 2010). 
This analysis showed that only Group 1 had actual Eigen value greater than simulated Eigen value derived from PA SPSS syntax (see Appendix C). Groups 2 and 3 did not meet set criteria and hence were eliminated from the analysis. Consequently, there is significant difference between the actual Eigen values from dataset and simulated Eigen values output of Parallel Analysis (PA) and the null hypothesis (HO3) was rejected. Moreover, the final 4 observed variables or factors in Group 1 (one) presented with varied factor loadings; increased work load during the pandemic (0.932), received recognition/commendation for sales efforts during lockdown (0.771), enlightenment \& information provider (0.631) and increased sales of products (0.615). The factor score ranking were shown to be Q3 $>Q^{2}>Q_{1}>Q^{4}$. It is suggested that 'increased work load' experienced by PSRs, was the workattribute with the highest relevance rating. Hence, the null hypothesis (HO4) was rejected.

Table 5.

Comparison between Study Eigen Values and Simulated Eigen Values.

\begin{tabular}{c|c|c|c|c}
\hline Component & \% of Variance & Study Eigen & Simulated Eigen & Decision \\
\hline 1 & 43.473 & 5.651 & 1.489 & Accept \\
\hline 2 & 10.367 & 1.348 & 1.362 & Reject \\
\hline 3 & 8.628 & 1.122 & 1.267 & Reject \\
\hline 4 & 5.873 & 0.764 & 1.185 & Reject \\
\hline 5 & 5.372 & 0.698 & 1.112 & Reject \\
\hline 6 & 5.002 & 0.650 & 1.045 & Reject \\
\hline 7 & 4.561 & 0.593 & 0.982 & Reject \\
\hline 8 & 3.535 & 0.460 & 0.917 & Reject \\
\hline 9 & 3.362 & 0.437 & 0.857 & Reject \\
\hline 10 & 3.268 & 0.425 & 0.795 & Reject \\
\hline 11 & 2.400 & 0.312 & 0.733 & Reject \\
\hline 12 & 2.310 & 0.300 & 0.667 & Reject \\
\hline 13 & 1.849 & 0.240 & 0.591 & Reject \\
\hline
\end{tabular}

Note: Decision rule; remove components when simulated Eigen is greater than actual Eigen \& vice-versa

\section{Conclusion and Practice Implications}

The strength of this study is that it puts in practice-perspective, the application of exploratory factor analysis in pharmaceutical sales and marketing research where knowledge, attitudes, practice, and perception-based questionnaires are often used for investigations. It is relevant to mention that the outcome of this study provides improved subjective thinking for pharmaceutical industry managers to explore appropriate constructs for phenomenon, sales process, marketing strategies and propound practice-based theories. Therefore, invariably to develop appropriate hypothesis or theory.

In addition, the parsimony effect achieved from factor analysis is very apt for middle and senior level managers who are inundated with large volume/s of data and information from which executive summaries are required for strategy formulation and implementation. This quantitative tool saves time, effort and impacts on the profitability of pharmaceutical firms and individuals.

On the policy level, as mentioned above, the use of exploratory factor analysis is significantly useful in informing decision making at the strategic, tactical, and operational levels of management in pharmaceutical sales and marketing companies, as it enables decision makers to identify, isolate the key issues/factors to be considered and the construct or context involved. This serves as a very informative strategy for filtering through large datasets, to relevant, manageable groupings with common characterization, in order to improve the quality, efficiency and generalizability of decisions. This tool finds application in research where content analysis is done as it ensures that critical/relevant data elements are fully considered. 


\subsection{Limitations of the Study}

There were some limitations to this study, Limited sample size due to the unavailability of reliable database of pharmaceutical sales representatives in Nigeria. Although, sample size met criteria for use in exploratory factor analysis. Also, the number of questions in the questionnaire can also be increased with further literature search.

\section{Abbreviations}

Pharmaceutical sales representatives (PSR), Exploratory Factor Analysis (EFA), Principal Component Analysis (PCA), Principal Axis Factoring (PAF), Parallel analysis (PA),

\section{References}

Adeloye, D., David, R. A., Olaogun, A. A., Auta, A., Adesokan, A., Gadanya, M., . . Iseolorunkanmi, A. (2017). Health workforce and governance: The crisis in Nigeria. Human Resources for Health, 15(1), 1-8.

Afriyie, D. O., Nyoni, J., \& Ahmat, A. (2019). The state of strategic plans for the health workforce in Africa. BMJ Global Health, 4(Suppl 9), e001115.Available at: https://doi.org/10.1136/bmjgh-2018-001115.

Ayati, N., Saiyarsarai, P., \& Nikfar, S. (2020). Short and long term impacts of COVID-19 on the pharmaceutical sector. DARU Journal of Pharmaceutical Sciences, 28(2), 799-805.Available at: https://doi.org/10.1007/s40199-020-00358-5.

Berliner, D. C. (2002). Comment: Educational research: The hardest science of all. Educational Researcher, 31(8), 18-20.

Cokluk, Ö., \& Koçak, D. (2016). Using Horn's parallel analysis method in exploratory factor analysis for determining the number of factors. Educational Sciences: Theory \& Practice, 16(2), 37-551.

Conway, J. M., \& Huffcutt, A. I. (2003). A review and evaluation of exploratory factor analysis practices in organizational research. Organizational Research Methods, 6(2), 147-168.Available at: https://doi.org/10.1177/1094428103251541.

Cronbach, L. J. (1946). Response sets and test validity. Educational and Psychological Measurement, 6(4), 475-494.Available at: https://doi.org/10.1177/001316444600600405.

Dahling, J. J., Chau, S. L., Mayer, D. M., \& Gregory, J. B. (2012). Breaking rules for the right reasons? An investigation of prosocial rule breaking. Journal of Organizational Behavior, 33(1), 21-42.Available at: https://doi.org/10.1002/job.730.

Debasish, S. S. (2004). Exploring customer preference for life insurance in india-factor analysis method. Vilakshan: XIBM Journal of Management, 1(1), 7-15.

Elbeddini, A., \& Yeats, A. (2020). Pharmacist intervention amid the coronavirus disease 2019 (COVID-19) pandemic: From direct patient care to telemedicine. Journal of Pharmaceutical Policy and Practice, 13(1), 1-4.Available at: https://doi.org/10.1186/s40545-020-00229-z.

Fabrigar, L. R., Wegener, D. T., MacCallum, P. C., \& Straham, E. J. (1999). Evaluating the use of exploratory factor analysis in psychological research. Psychological Methods, 4(3), 272-299.Available at: https://doi.org/10.1037/ 1082-989x.4.3.272.

Goretzko, D., Pham, T. T. H., \& Bühner, M. (2019). Exploratory factor analysis: Current use, methodological developments and recommendations for good practice. Current Psychology, 1-12.Available at: https://doi.org/10.1007/s12144-01900300-2.

Gray, A., Hoffman, J., \& Mansfield, P. (2020). Pharmaceutical sales representatives: The Politics of medicines (eEncyclopedia). Retrieved from: https://haiweb.org/encyclopaedia/pharmaceutical-sales-representative/. [Accessed online November 2020].

Henson, R. K., Capraro, R. M., \& Capraro, M. M. (2004). Reporting practice and use of extraction factor analysis in educational research journals. Research in Schools, 11(2), 61-72.

Horn, J. L. (1965). A rationale and test for the number of factors in factor analysis. Psychometrika, 30(2), 179-185.Available at: https://doi.org/10.1007/bfo2289447.

Izquierdo, I., Olea, J., \& Abad, F. J. (2014). Exploratory factor analysis in validation studies: Uses and recommendations. Psicothema, 26(3), 395-400.Available at: 10.7334/psicothema2013.349.

Kahn, J. H. (2006). Factor analysis in counseling psychology research, training, and practice: Principles, advances, and applications. The Counseling Psychologist, 34(5), 684-718.Available at: https://doi.org/10.1177/001 1000006286347.

Ledesma, R. D., \& Valero-Mora, P. (2007). Determining the number of factors to retain in EFA: An easy-to-use computer program for carrying out parallel analysis. Practical Assessment, Research, and Evaluation, 12(1), 1-11.

Luigi, D., TTichindelean, M., \& Vinerean, S. (2013). Using factor analysis in relationship marketing. Procedia Economics and Finance, 6, 466-475.Available at: https://doi.org/10.1016/s22 12-5671(13)00164-0.

Matsunaga, M. (2010). How to factor-analyse your data right; Do's, Don'ts and How-to's. International Journal of Psychological Research., 3(1), 97-110.

Mvududu, N. H., \& Sink, C. A. (2013). Factor analysis in counseling research and practice. Counseling Outcome Research and Evaluation, 4(2), 75-98.Available at: https://doi.org/10.1177/2150137813494766.

Nimalathasan, B. (2009). Factor analysis: Nature, mechanism and uses in social and management science research. Journal of Cost and Management Accountant, Bangladesh, 37(2), 15-25. 
Nimon, K., Zigarmi, D., Houson, D., Witt, D., \& Diehl, J. (2011). The work cognition inventory: Initial evidence of construct validity. Human Resource Development Quarterly, 22(1), 7-35.Available at: https://doi.org/10.1002/hrdq.20065.

O'Connor, B. P. (2000). SPSS and SAS programs determining the number of components using parallel analysis and Velicer's MAP test. Behavior Research Methods, Instruments, \& Computer, 32, 396-402.Available at: https;/doi.org/10/10.3758/BFo3200807.

Oamen, T. E. (2021). COVID-19 Pandemic and impact on pharmaceutical sales representatives' operations in West Africa; A socio-demographic case study of Nigeria. African Journal of Social Science and Humanities Research, 4(1), 59-72.

Obuaku, C. (2014). Essential medicines in Nigeria: Foregrounding access to affordable essential medicines. African Sociological Review/Revue Africaine de Sociologie, 18(2), 42-60.

Ozturk, M. A. (2011). Confirmatory factor analysis of the Educators' Attitudes toward educational Research scale. Educational Sciences: Theory and Practice, 11(2), 737-748.

Pett, M. A., Lackey, N. R., \& Sullivan, J. J. (2003). Making sense of factor analysis; The use of factor analysis for instrument development in healthcare research. Thousand Oaks, CA: Sage.

Reio Jr, T. G., \& Shuck, B. (2015). Exploratory factor analysis: Implications for theory, research, and practice. Advances in Developing Human Resources, $17(1)$, 12-25.Available at: 10.1177/15234223 14559804 .

Schreiber, J. B. (2020). Issues and recommendations for exploratory factor analysis and principal component analysis. Research in Social and Administrative Pharmacy, 15:S1551-7411(20), 30746-30744.Available at: 10.1016/j.sapharm.2020.07.027.

Tabachnick, B. G., \& Fidell, L. S. (2007). Using multivariate statistics (5th ed.). Boston. MA: Allyn and Bacon.

Thompson, B. (2004). Exploratory and confirmatory factor analysis. Washington DC: American Psychological Association.

Treiblmaier, H., \& Filzmoser, P. (2010). Exploratory factor analysis revisited: How robust methods support the detection of hidden multivariate data structures in IS research. Information $\oint^{\circ}$ Management, 47(4), 197-207.Available at: https://doi.org/10.1016/j.im.2010.02.002.

Ugbam, O. C., \& Okoro, E. A. (2017). A strategic study of the Nigerian pharmaceutical sector: Organizational leadership, market-share, and competitive performance. International Journal of Business, Humanities and Technology, 7(1), 1-10.

Van De Tran. (2019). Factors influencing community pharmacists' recommendation of over-the-counter medications in four Vietnam cities. Tropical Journal of Pharmaceutical Research, 18(2), 421-427.Available at: https;//dx.doi.org/10.4314/tjpr.v 18:2.29.

Watterson, T. L., Look, K. A., Steege, L., \& Chui, M. A. (2020). Operationalizing occupational fatigue in pharmacists: An exploratory factor analysis. Research in Social and Administrative Pharmacy, 25: S1551-7411(20), 31111-31116.Available at: 10.1016 /j.sapharm.2020.09.012.

WHO. (2010). Key components of a well-functioning health system. Geneva, Switzerland: World Health Organisation. 


\section{Appendix A}

\begin{tabular}{|c|c|c|c|c|c|c|c|c|c|c|c|c|c|c|}
\hline \multicolumn{15}{|c|}{ Correlation Matrix } \\
\hline & & $\begin{array}{l}\text { Enlighti } \\
\text { ngment } \\
\& \\
\text { Informat } \\
\text { ion } \\
\text { Provider }\end{array}$ & $\begin{array}{l}\text { Received } \\
\text { recognition/co } \\
\text { mmendation } \\
\text { for your sales } \\
\text { efforts during } \\
\text { the pandemic }\end{array}$ & $\begin{array}{l}\text { Increa } \\
\text { sed } \\
\text { work } \\
\text { load }\end{array}$ & $\begin{array}{l}\text { 1 Increase } \\
\mathrm{d} \text { sales of } \\
\text { your } \\
\text { products }\end{array}$ & $\begin{array}{l}\text { Involved in } \\
\text { community } \\
\text { education }\end{array}$ & $\begin{array}{l}\text { Improved } \\
\text { access to } \\
\text { your } \\
\text { customers }\end{array}$ & $\begin{array}{l}\text { Limited } \\
\text { access to } \\
\text { your } \\
\text { customer } \\
\text { s }\end{array}$ & $\begin{array}{l}\text { Observed } \\
\text { compliance } \\
\text { by people } \\
\text { during lock } \\
\text { down period }\end{array}$ & $\begin{array}{l}\text { Enjoyed } \\
\text { communi } \\
\text { ty } \\
\text { appreciati } \\
\text { on of } \\
\text { your } \\
\text { efforts }\end{array}$ & $\begin{array}{l}\text { Virtual } \\
\text { consultation } \\
\text { with } \\
\text { clients/cust } \\
\text { omers }\end{array}$ & $\begin{array}{l}\text { Limited } \\
\text { access to } \\
\text { Doctors, } \\
\text { nurses } \\
\text { \&amp; } \\
\text { pharmacis } \\
\text { ts }\end{array}$ & $\begin{array}{l}\text { Made fresh } \\
\text { contacts/n } \\
\text { ew } \\
\text { opportuniti } \\
\text { es for } \\
\text { business }\end{array}$ & $\begin{array}{l}\text { Involved } \\
\text { in } \\
\text { COVID- } \\
19 \\
\text { screening } \\
\text { activities }\end{array}$ \\
\hline & $\begin{array}{l}\text { Enlightingmen } \\
\mathrm{t} \text { \&amp; } \\
\text { Information } \\
\text { Provider }\end{array}$ & 1.000 & .569 & .491 & .398 & .464 & .400 & .268 & .509 & .482 & .493 & .240 & .423 & .174 \\
\hline & $\begin{array}{l}\text { Received } \\
\text { recognition/co } \\
\text { mmendation } \\
\text { for your sales } \\
\text { efforts during } \\
\text { the pandemic }\end{array}$ & .569 & 1.000 & .552 & .526 & .335 & .373 & .215 & .358 & .501 & .447 & .194 & .407 & .288 \\
\hline & $\begin{array}{l}\text { 1 Increased } \\
\text { work load }\end{array}$ & .491 & .552 & 1.000 & .539 & .274 & .449 & .243 & .357 & .318 & .316 & .187 & .463 & .203 \\
\hline & $\begin{array}{ll}\text { Increased } & \text { sales } \\
\text { of } & \text { your } \\
\text { products } & \\
\end{array}$ & .398 & .526 & .539 & 1.000 & .388 & .453 & .185 & .372 & .433 & .499 & .241 & .484 & .334 \\
\hline & $\begin{array}{l}\text { Involved in } \\
\text { community } \\
\text { education }\end{array}$ & .464 & .335 & .274 & .388 & 1.000 & .449 & .163 & .440 & .428 & .512 & .329 & .352 & .497 \\
\hline & $\begin{array}{l}\text { Improved } \\
\text { access to your } \\
\text { customers }\end{array}$ & .400 & .373 & .449 & .453 & .449 & 1.000 & .143 & .322 & .431 & .331 & .219 & .484 & .406 \\
\hline & $\begin{array}{l}\text { Limited access } \\
\text { to your } \\
\text { customers }\end{array}$ & .268 & .215 & .243 & .185 & .163 & .143 & 1.000 & .367 & .402 & .337 & .460 & .256 & .104 \\
\hline$\approx$ & $\begin{array}{l}\text { Observed } \\
\text { compliance by } \\
\text { people during } \\
\text { lock down } \\
\text { period }\end{array}$ & .509 & .358 & .357 & .372 & .440 & .322 & .367 & 1.000 & .514 & .523 & .462 & .478 & .177 \\
\hline $\mid$ & $\begin{array}{l}\text { Enjoyed } \\
\text { community } \\
\text { appreciation of } \\
\text { your efforys ournal }\end{array}$ & .482 & .501 & .318 & .433 & .428 & .431 & .402 & .514 & 1.000 & .608 & .356 & .489 & .416 \\
\hline
\end{tabular}

:

Vol. 3, No. 1, pp. 11-27, 2021

DOI: 10.33094/26410249.2021.31.11.27

(C) 2021 by the authors; licensee Learning Gate 


\begin{tabular}{|c|c|c|c|c|c|c|c|c|c|c|c|c|c|}
\hline $\begin{array}{l}\text { Virtual } \\
\text { consultation } \\
\text { with } \\
\text { clients/custom } \\
\text { ers }\end{array}$ & .493 & .447 & .316 & .499 & .512 & .331 & .337 & .523 & .608 & 1.000 & .532 & .573 & .349 \\
\hline $\begin{array}{l}\text { Limited access } \\
\text { to Doctors, } \\
\text { nurses \&amp; } \\
\text { pharmacists }\end{array}$ & .240 & .194 & .187 & .241 & .329 & .219 & .460 & .462 & .356 & .532 & 1.000 & .337 & .218 \\
\hline $\begin{array}{l}\text { Made fresh } \\
\text { contacts/new } \\
\text { opportunities } \\
\text { for business }\end{array}$ & .423 & .407 & .463 & .484 & .352 & .484 & .256 & .478 & .489 & .573 & .337 & 1.000 & .305 \\
\hline $\begin{array}{ll}\text { Involved } & \text { in } \\
\text { COVID-19 } & \\
\text { screening } & \\
\text { activities } & \end{array}$ & .174 & .288 & .203 & .334 & .497 & .406 & .104 & .177 & .416 & .349 & .218 & .305 & 1.000 \\
\hline
\end{tabular}

Note: a Determinant $=.003$ 


\section{Appendix B}

\section{Anti-image Matrices}

\begin{tabular}{|c|c|c|c|c|c|c|c|c|c|c|c|c|c|c|}
\hline \multirow[t]{7}{*}{$\begin{array}{l}\text { Anti- } \\
\text { image } \\
\text { Covari } \\
\text { ance }\end{array}$} & $\begin{array}{l}12 . \\
\text { SalesRepRel_Elighting } \\
\text { ment \&amp; } \\
\text { Information Provider }\end{array}$ & .473 & -.143 & -.092 & .047 & -.116 & -.050 & -.027 & -.095 & -.037 & -.061 & .059 & .001 & .105 \\
\hline & $\begin{array}{l}\text { SalesRepRel_Received } \\
\text { recognition/commendat } \\
\text { ion for your sales efforts } \\
\text { during the pandemic }\end{array}$ & -.143 & .492 & -.138 & -.099 & .028 & .021 & .021 & .025 & -.095 & -.026 & .019 & .013 & -.045 \\
\hline & $\begin{array}{l}12 . \\
\text { SalesRepRel_Increased } \\
\text { work load }\end{array}$ & -.092 & -.138 & .510 & -.144 & .028 & -.093 & -.076 & -.030 & .068 & .052 & .003 & -.090 & .003 \\
\hline & $\begin{array}{l}12 . \\
\text { SalesRepRel_Increased } \\
\text { sales of your products }\end{array}$ & .047 & -.099 & -.144 & .524 & -.027 & -.070 & .023 & -.019 & -.008 & -.093 & .027 & -.039 & -.032 \\
\hline & $\begin{array}{l}12 . \\
\text { SalesRepRel_Involved } \\
\text { in community education }\end{array}$ & -.116 & .028 & .028 & -.027 & .515 & -.101 & .043 & -.093 & .023 & -.086 & -.027 & .054 & -.205 \\
\hline & $\begin{array}{l}12 . \\
\begin{array}{l}\text { SalesRepRel_Improved } \\
\text { access to your } \\
\text { customers }\end{array}\end{array}$ & -.050 & .021 & -.093 & -.070 & -.101 & .568 & .044 & .022 & -.078 & .080 & -.032 & -.127 & -.092 \\
\hline & $\begin{array}{l}12 . \\
\text { SalesRepRel_Limited } \\
\begin{array}{l}\text { access to your } \\
\text { customers }\end{array}\end{array}$ & -.027 & .021 & -.076 & .023 & .043 & .044 & .687 & -.042 & -.137 & .010 & -.210 & .007 & .027 \\
\hline & $\begin{array}{l}12 . \\
\text { SalesRepRel_Obse } \\
\text { rved compliance } \\
\text { by people during } \\
\text { lock down period }\end{array}$ & -.095 & .025 & -.030 & -.019 & -.093 & .022 & -.042 & .520 & -.094 & -.009 & -.123 & -.083 & .087 \\
\hline
\end{tabular}




\begin{tabular}{|c|c|c|c|c|c|c|c|c|c|c|c|c|c|c|}
\hline & $\begin{array}{l}12 . \\
\text { SalesRepRel_Enjo } \\
\text { yed community } \\
\text { appreciation of } \\
\text { your efforts }\end{array}$ & -.037 & -.095 & .068 & -.008 & \begin{tabular}{|l|}
.023 \\
\end{tabular} & -.078 & -.137 & $\begin{array}{l}-094 \\
\end{array}$ & .443 & -.105 & .044 & -.027 & -.116 \\
\hline & $\begin{array}{l}\text { 12. } \\
\text { SalesRepRel_Virt } \\
\text { ual consultation } \\
\text { with } \\
\text { clients/customers }\end{array}$ & -.061 & -.026 & .052 & -.093 & -.086 & .080 & .010 & -.009 & -.105 & .377 & -.156 & -.130 & -.007 \\
\hline & $\begin{array}{l}12 . \\
\text { SalesRepRel_Limi } \\
\text { ted access to } \\
\text { Doctors, nurses } \\
\text { \&amp; } \\
\text { pharmacists }\end{array}$ & .059 & .019 & .003 & .027 & -.027 & -.032 & -.210 & -.123 & .044 & -.156 & .579 & .003 & -.029 \\
\hline & $\begin{array}{l}12 . \\
\text { SalesRepRel_Mad } \\
\text { e fresh } \\
\text { contacts/new } \\
\text { opportunities for } \\
\text { business }\end{array}$ & .001 & .013 & -.090 & -.039 & \begin{tabular}{|l|}
.054 \\
\end{tabular} & -.127 & .007 & -.083 & -.027 & -.130 & .003 & .511 & -.026 \\
\hline & $\begin{array}{l}12 . \\
\text { SalesRepRel_Invo } \\
\text { lved in COVID-19 } \\
\text { screening } \\
\text { activities }\end{array}$ & .105 & -.045 & .003 & -.032 & -.205 & -.092 & .027 & .087 & -.116 & -.007 & -.029 & -.026 & .622 \\
\hline $\begin{array}{l}\text { Anti-image } \\
\text { Correlation }\end{array}$ & $\begin{array}{l}12 . \\
\text { SalesRepRel_Elig } \\
\text { htingment \&amp; } \\
\text { Information } \\
\text { Provider }\end{array}$ & $.874^{\mathrm{a}}$ & -.297 & -.187 & .093 & -.236 & -.096 & -.047 & -.192 & -.080 & -.144 & .112 & .003 & .194 \\
\hline & $\begin{array}{lr}\text { SalesRepRel_Rece } \\
\text { ived } \\
\text { recognition/comm } \\
\text { endation for your } \\
\text { sales efforts } \\
\begin{array}{llr}\text { during the } \\
\text { pandemic }\end{array}\end{array}$ & -.297 & $.887^{\mathrm{a}}$ & -.275 & -.195 & .056 & .039 & .037 & .050 & -.204 & -.061 & .036 & .026 & -.082 \\
\hline & $\begin{array}{l}12 . \\
\text { SalesRepRel_Incr } \\
\text { eased work load }\end{array}$ & -.187 & -.275 & $.854^{\mathrm{a}}$ & -.278 & \begin{tabular}{|l|}
.054 \\
\end{tabular} & -.173 & -.129 & -.058 & .144 & .119 & .005 & -.177 & .005 \\
\hline & $\begin{array}{l}12 . \\
\text { SalesRepRel_Incr } \\
\text { eased sales of your } \\
\text { products }\end{array}$ & .093 & -.195 & -.278 & $.913^{\mathrm{a}}$ & -.053 & -.128 & .039 & -.037 & -.017 & -.208 & .049 & -.076 & -.055 \\
\hline
\end{tabular}

Journal of Contemporary Research in Social Sciences ISSN : 2641-0249

Vol. 3, No. 1, pp. 11-27, 2021

DOI: $10.33094 / 26410249.2021 .31 .11 .27$

(C) 2021 by the authors; licensee Learning Gate 


\begin{tabular}{|c|c|c|c|c|c|c|c|c|c|c|c|c|c|}
\hline $\begin{array}{l}12 . \\
\text { SalesRepRel_Invo } \\
\text { lved in community } \\
\text { education }\end{array}$ & -.236 & .056 & .054 & -.053 & $.855^{\mathrm{a}}$ & -.187 & .073 & -.179 & .048 & -.196 & -.049 & $\begin{array}{l}.106 \\
\end{array}$ & -.963 \\
\hline $\begin{array}{l}12 . \\
\text { SalesRepRel_Impr } \\
\text { oved access to } \\
\text { your customers }\end{array}$ & -.096 & .039 & -.173 & -.128 & -.187 & $.883^{\mathrm{a}}$ & .071 & $.04 \cdot 1$ & -.156 & .173 & -.056 & -.235 & -.155 \\
\hline $\begin{array}{l}12 . \\
\text { SalesRepRel_Limi } \\
\text { ted access to your } \\
\text { customers }\end{array}$ & -.047 & .037 & -.129 & .039 & .073 & .071 & $.819^{\mathrm{a}}$ & -.071 & -.248 & .020 & -.333 & .012 & .042 \\
\hline $\begin{array}{l}12 . \\
\text { SalesRepRel_Obse } \\
\text { rved compliance } \\
\text { by people during } \\
\text { lock down period }\end{array}$ & -.192 & .050 & -.058 & -.037 & -.179 & .041 & -.071 & $.905^{\mathrm{a}}$ & -.196 & -.021 & -.224 & -.161 & .152 \\
\hline $\begin{array}{l}12 . \\
\text { SalesRepRel_Enjo } \\
\text { yed community } \\
\text { appreciation of } \\
\text { your efforts }\end{array}$ & -.080 & -.204 & .144 & -.017 & .048 & -.156 & -.248 & $\begin{array}{l}-.196 \\
\end{array}$ & $.885^{\mathrm{a}}$ & -.256 & .086 & -.058 & -.220 \\
\hline $\begin{array}{l}\text { 12. } \\
\text { SalesRepRel_Virt } \\
\text { ual consultation } \\
\text { with } \\
\text { clients/customers }\end{array}$ & -.144 & \begin{tabular}{l|l}
-.061 \\
\end{tabular} & .119 & -.208 & $\begin{array}{l}-196 \\
\end{array}$ & .173 & .020 & -.021 & -.256 & $.865^{\mathrm{a}}$ & -.334 & -.295 & -.014 \\
\hline $\begin{array}{l}12 . \\
\text { SalesRepRel_Limi } \\
\text { ted access to } \\
\text { Doctors, nurses } \\
\text { \&amp; } \\
\text { pharmacists }\end{array}$ & .112 & .036 & .005 & .049 & $\begin{array}{l}-.049 \\
\end{array}$ & $\begin{array}{l}-.056 \\
\end{array}$ & -.333 & $\begin{array}{l}-.224 \\
\end{array}$ & .086 & $\begin{array}{l}.334 \\
\end{array}$ & $.815^{\mathrm{a}}$ & .006 & -.048 \\
\hline $\begin{array}{l}12 . \\
\text { SalesRepRel_Mad } \\
\text { e fresh } \\
\text { contacts/new } \\
\text { opportunities for } \\
\text { business }\end{array}$ & .003 & $\begin{array}{l}.026 \\
\end{array}$ & -.177 & -.076 & .106 & -.235 & .012 & -.161 & -.058 & -.295 & $\begin{array}{l}.006 \\
\end{array}$ & $.909^{\mathrm{a}}$ & -.046 \\
\hline $\begin{array}{l}12 . \\
\text { SalesRepRel_Invo } \\
\text { lved in COVID-19 } \\
\text { screening } \\
\text { activities }\end{array}$ & $\begin{array}{l}.194 \\
\end{array}$ & $\begin{array}{l}-.082 \\
\end{array}$ & .005 & -.055 & -.363 & -.155 & .042 & .152 & -.220 & -.014 & -.048 & $\begin{array}{l}-.046 \\
\end{array}$ & $.804^{\mathrm{a}}$ \\
\hline
\end{tabular}




\begin{tabular}{|c|c|c|}
\hline \multicolumn{3}{|c|}{ APPENDIX C } \\
\hline \multicolumn{3}{|c|}{ Run MATRIX procedure: } \\
\hline \multicolumn{3}{|c|}{ PARALLEL ANALYSIS: } \\
\hline \multicolumn{3}{|c|}{ Principal Components } \\
\hline \multicolumn{3}{|c|}{ Specifications for this Run: } \\
\hline Ncases 170 & & \\
\hline Nvars & \\
\hline Ndatsets 100 & & \\
\hline \multicolumn{3}{|l|}{ Percent 95} \\
\hline \multicolumn{3}{|c|}{ Random Data Eigenvalues } \\
\hline Root & Means & Prcntyle \\
\hline 1.000000 & 1.487263 & 951 \\
\hline 2.000000 & 1.361819 & 1.4 \\
\hline 3.000000 & 1.268654 & 1.32 \\
\hline 4.000000 & 1.189559 & 1.253058 \\
\hline 5.000000 & 1.112264 & 1.167250 \\
\hline 6.000000 & 1.043547 & 1.093500 \\
\hline 7.000000 & .982047 & 1.034188 \\
\hline 8.000000 & .915869 & .963639 \\
\hline 9.000000 & .860102 & .914552 \\
\hline 10.000000 & .794516 & .845542 \\
\hline 11.000000 & .730411 & .790955 \\
\hline 12.000000 & .666823 & .722993 \\
\hline 13.000000 & .587127 & .648472 \\
\hline
\end{tabular}

\section{END MATRIX}

Run MATRIX procedure:

PARALLEL ANALYSIS:

Principal Axis / Common Factor Analysis Specifications for this Run:

Ncases 170

Nvars 13

Ndatsets 100

Percent 95

Random Data Eigenvalues

$\begin{array}{ccc}\text { Root } & \text { Means } & \text { Prcntyle } \\ 1.000000 & .574874 & .730443 \\ 2.000000 & .441504 & .533296 \\ 3.000000 & .344494 & .416104 \\ 4.000000 & .259157 & .340470 \\ 5.000000 & .177857 & .246647 \\ 6.000000 & .107057 & .159605 \\ 7.000000 & .043543 & .097616 \\ 8.000000 & -.021244 & .027822 \\ 9.000000 & -.075835 & -.027596 \\ 10.000000 & -.137023 & -.097777 \\ 11.000000 & -.195529 & -.154165 \\ 12.000000 & -.254016 & -.214330 \\ 13.000000 & -.325739 & -.278526\end{array}$

Journal of Contemporary Research in Social Sciences ISSN : 264.1-0249

Vol. 3, No. 1, pp. 11-27, 2021

DOI: 10.33094/26410249.2021.31.11.27

(C) 2021 by the authors; licensee Learning Gate 